\title{
ANALISIS PENERAPAN SEGMENTING, TARGETING, DAN POSITIONING PADA PERUSAHAAN DAPUR TAHU ALAMI LUBUK BUAYA PADANG
}

\author{
Asrizal ${ }^{1)}$, Monika Nur Oktavia ${ }^{2)}$ \\ Fakultas Ekonomi, Universitas Muhammadiyah Sumatera Barat 1) 2) \\ asrizalzen@gmail.com ${ }^{1)}$,monikaoktavia428@gmail.com ${ }^{2)}$
}

\begin{abstract}
The purpose of the study was to determine the application of segmenting, targeting, and positioning carried out by the Lubuk Buaya Padang Natural Tofu Kitchen Company. This research is descriptive research. Data was collected by using interview methods and questionnaires. The data analysis technique was carried out using Editing, Classification, Verification, Analysis, and Concluding techniques. From the research results, it is found that the Company has implemented geographic, demographic, psychographic, and behavioral segmentation. For the target market, the Company has targeted the main target market for the Koto Tangah area, and the surrounding environment. And for the market position, white tofu is known to be natural tofu without a chewing agent, yellow tofu is known to have natural turmeric color without a thickener, and meatball tofu is known to have natural tofu with a meatball flavor without any elasticity.
\end{abstract}

Keywords: Segmenting, Targeting, positioning

Abstrak : Tujuan penelitian untuk mengetahui penerapan segmenting, targeting, dan positioning yang dilakukan oleh Perusahaan Dapur Tahu Alami Lubuk Buaya Padang. Penelitian ini merupakan penelitian deskriptif. Pengumpulan data dilakukan dengan metode wawancara, dan kuesioner. Teknik analisis data yang dilakukan dengan menggunakan teknik Editing, Classification, Verification, Analysis, dan Concluding. Dari hasil penelitian, didapatkan hasil bahwa Perusahaan telah menerapkan segmentasi secara geografis, demografis, psikografis, dan perilaku. Untuk target pasar Perusahaan sudah menargetkan pasar sasaran utama wilayah Koto Tangah, dan lingkungan sekitarnya. Dan untuk posisi pasar tahu putih dikenal tahu alami tanpa pengenyal, tahu kuning dikenal tahu alami warna kunyit tanpa pengenyal, dan tahu bakso dikenal tahu alami rasa bakso tanpa pengenyal.

Kata Kunci : Segmenting, Targeting, positioning

\section{A. PENDAHULUAN}

Kebutuhan manusia banyak, beraneka ragam, bahkan tidak hanya beraneka ragam, tetapi bertambah terus, tidak ada habisnya sejalan dengan perkembangan peradapan dan kemajuan ilmu pengetahuan dan teknologi.

Untuk memenuhi akan kebutuhan dan keinginan konsumen tersebut, salah satunya kebutuhan terhadap produk tahu, diantaranya dapat dihasilkan oleh perusahaan berskala mikro dan kecil. Perusahaan berskala mikro dan kecil dapat dijalankan oleh perorangan, rumah tangga, maupun badan usaha kecil. Perusahaan mikro banyaknya tenaga kerja1-4 orang, Perusahaan kecil banyaknya tenaga kerja 5-19 orang (BPS)

Salah satu perusahaan kecil yang ada dikota Padang yang menyediakan kebutuhan komsumsi tahu adalah perusahaan Dapur Tahu Alami. Keberhasilan perusahaan tahu tersebut dalam memahami memenuhi, dan keinginan konsumen, ditentukan bagaimana perusahaan melakukan segmenting, targeting, dan positioning pasarnya.

Hasil penelitian menunjukan, masih adanya perusahaan mikro dan kecil belum fokus terhadap segementing, targeting dan positiong pasarnya (Manggu dan Beni ,2021), tetapi ada juga perusahaan yang telah melakukan segmenting, targeting, dan positioning pasarnya (Wijaya \& Hani, 2016)

Segmenting pasar sebagai proses mengelompokkan pasar keseluruhan yang berbeda-beda menjadi kelompok-kelompok atau segmen-segmen yang memiliki kesamaan dalam hal kebutuhan dan keinginan (Tjiptono, 2008, Kotler dan Armstrong 2008) 
Dasar-dasar untuk membuat segmenting pasar (Tjiptono, 2008, Kotler dan Armstrong, 2008) konsumen terdiri dari segmenting geografis, segmenting demografis, segmenting psikografis, dan segmenting perilaku. Segmenting geografis membagi pasar menjadi berbagai unit geografis seperti propinsi, kabupaten, kota, dan kecamatan . Segmenting demografis membagi pasar menjadi kelompok berdasarkan variabel seperti usia, jenis kelamin, ukuran keluarga, siklus hidup keluarga, pendapatan, pekerjaan, pendidikan, agama, ras, generasi, dan kebangsaan. Segmenting Psikografis membagi pasar menjadi kelompok berdasarkan kelas sosial, gaya hidup, atau karakteristik kepribadian. Orang-orang dalam kelompok geografis yang sama bisa memiliki komposisi psikografis yang sangat berbeda. Segmenting perilaku membagi pembeli menjadi kelompok berdasarkan pengetahuan, sikap, penggunaan, atau respon terhadap sebuah produk.

Setelah melakukan identifikasi segmen pasar, selanjutnya mengevaluasi beragam segmen, dan memutuskan berapa banyak dan segmen mana yang akan ditarget. Target pasar adalah proses mengevaluasi dan memilih satu atau beberapa segmen pasar yang dinilai paling menarik untuk dilayani dengan program pemasaran khusus (Tjiptono, 2008).

Setelah menentukan segmen dan target pasar dengan menentukan positioning pasarnya. Menurut Philip Kotler positioning adalah aktivitas mendesain citra dari apa yang ditawarkan perusahaan sehingga mempunyai arti dan memosisikan diri di benak konsumen. Sedangkan bagi Yoram Wind positioning adalah bagaimana mendefinisikan identitas dan kepribadian perusahaan di benak pelanggan (Kartajaya dan Sula, 2006). Jadi, positioning adalah suatu pernyataan mengenai bagaimana identitas produk atau perusahaan tertanam di benak konsumen yang mempunyai kesesuaian dengan kompetensi yang dimiliki perusahaan untuk mendapat kepercayaan, kredibilitas, dan pengakuan dari konsumen.

Untuk mendapatkan keunggulan kompetitif, perusahaan perlu mengembangkan strategi penentuan posisi produk ke pasar sasaran yang dituju. Dengan demikian penentuan posisi produk lebih memfokuskan pada apa produk itu, seperti apa produk itu, dan bagaimana pelanggan harus mengevaluasinya. Perusahaan harus mengetahui persepsi dan preferensi pembeli mengenai produk yang ditawarkan. Pemosisian produk menyangkut posisi suatu merek dalam benak konsumen sedemikian rupa, sehingga dipersepsikan unik dan unggul dibandingkan merek pesaing dalam hal atribut dan manfaat produk.

Berdasarkan latar belakang tersebut adapun tujuan penelitian adalah untuk mengetahui penerapan segmentasi (segmenting) pasar, penentuan pasar sasaran (targeting), dan penempatan posisi (positioning) pada perusahaan Dapur Tahu Alami kota Lubuk Buaya Padang.

\section{B. METODE PENELITIAN}

Penelitian ini menggunakan metode deskriptif. Metode penelitian deskriptif bertujuan untuk membuat deskripsi, gambaran, sifat-sifat serta hubungan antar fenomena yang diselidiki (Nazir, 1988, Sakaran 2011). Penelitian dilakukan di Perusahaan Dapur Tahu Alami Lubuk Buaya Kecamatan Koto Tangah Padang. Pengumpulan data dilakukan dengan metode wawancara, dan kuesioner. Teknik analisis data yang dilakukan dengan menggunakan teknik Editing, Classification, Verification, Analysis, dan Concluding

\section{HASIL DAN PEMBAHASAN}

Perusahaan Dapur Tahu Alami merupakan salah satu perusahaan kecil, yang melakukan produksi setiap harinya, sesuai dengan kebutuhan dan keinginan konsumen. Perusahaan Dapur Tahu Alami berdiri sejak tahun 1999 yang didirikan oleh ibu Habibah, dan bapak Muakhir yang berasal dari Jawa. Proses produksi tahu dilakukan tepat dibelakang rumah ibu Habibah yang berada didepan jalan Adinegoro No. 13, Lubuk Buaya, Kecamatan Koto Tangah, Kota Padang, Sumatera Barat, 25173. 


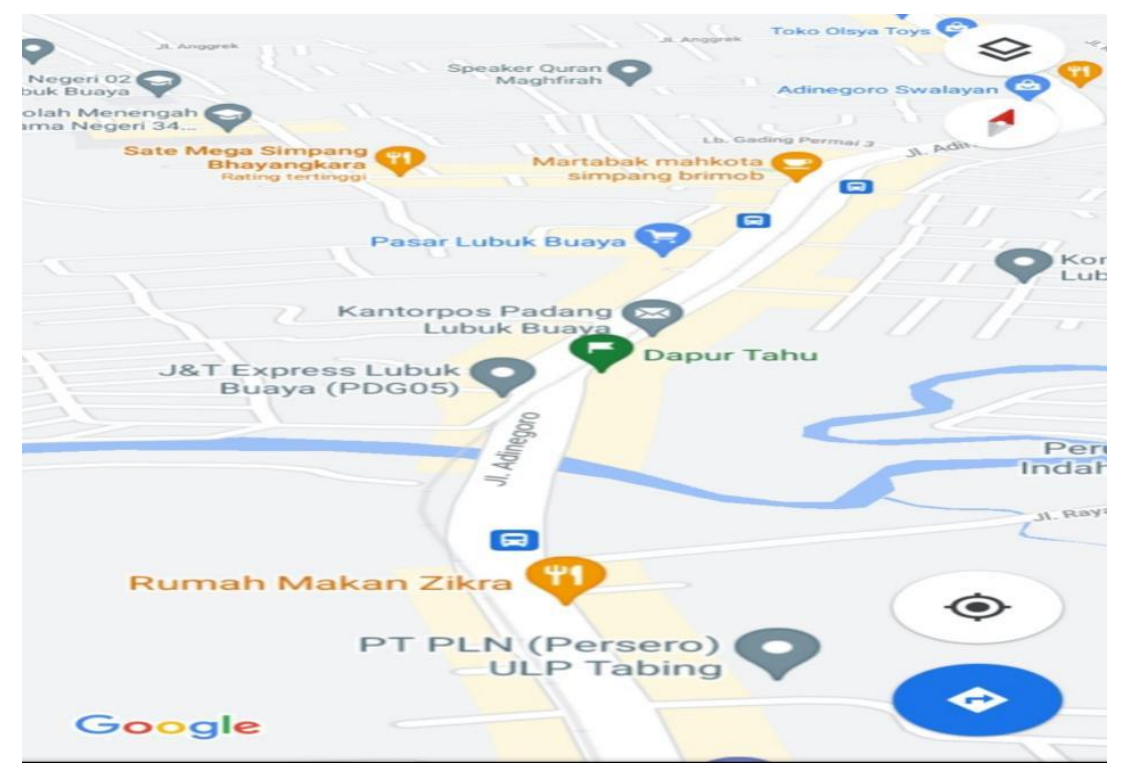

\section{Gambar : Peta Lokasi Perusahaan Dapur Tahu Alami}

\section{Segmenting}

Dari sisi segmen geografi Perusahaan Dapur Tahu Alami menjadikan kecamatan koto tangah kota Padang sebagai sasaran pasar yang utama, dan juga kecamatan lainnya tetapi tidak menjadi sasaran pasar yang utama.

Dari sisi segmen demografi, produksi tahu tanpa pengawet/pengenyal yang ditujukan untuk semua umur seperti balita, anak-anak, remaja, dewasa, dan orang tua, serta tidak membedakan jenis kelamin, baik laki maupun perempuan. Dari segi pendapatan tahu yang diproduksi relatif murah, sehingga bisa dikomsumsi mulai dari pendapatan yang rendah, menengah, dan tinggi serta dapat dikomsumsi untuk semua kalangan yang berpendidikan, dan yang tidak perpendidikan.

Dari sisi psikografis produksi tahu ditujukan untuk semua kelas social dengan tidak membedakan kelas rendah, menengah, dan tinggi. Karena harga tahu yang diproduksi murah. Dilihat dari gaya hidup pemenuhan kebutuhan konsumen biasanya didasarkan pada persepsi dan motivasi, hal ini mempengaruhi cara mereka dalam mengkomsumsi tahu. Konsumen yang dengan kebutuhan tinggi terhadap tahu akan mengkomsumsi tahu dalam jumlah banyak berbeda dengan konsumen yang memiliki kebutuhan sedang atau rendah akan mengkomsumsi tahu dengan jumlah sedikit. Berdasarkan hasil penelitian yang telah dilakukan pada perusahaan Dapur Tahu Alami, maka komsumsi tahu dikategorikan tinggi karena penjualannya tinggi dan tersebar di berbagai wilayah. Dilihat dari segi karakteristik kepribadian konsumen yang suka tahu akan lebih sering mengkomsumsi tahu dibandingkan dengan konsumen yang tidak terlalu suka tahu.

Dari sisi perilaku produk tahu memiliki banyak manfaat, diantaranya tahu mengandung protein termasuk asam amino esensial, berbagai vitamin dan mineral seperti mangan, kalsium, selenium, fosfor, magnesium ,zat besi dan lain-lain. Dengan adanya manfaat tahu tersebut sehingga loyalitas konsumen meningkat terhadap tahu yang diproduksi. Dilihat dari penggunaan/komsumsi tahu bukan merupakan makanan pokok, sehingga konsumen tidak terlalu ketergantungan dalam mengkomsumsi tahu, jadi komsumsi tahu ini hanya didasarkan pada keinginan bukan kebutuhan.

\section{Targeting}

Perusahaan Dapur Tahu Alami menghasilkan produk tahu yang terdiri dari tahu putih, tahu kuning, dan tahu bakso.

Sasaran pasar utama jenis tahu putih ditujukan ke wilayah Koto Tangah, dan lingkungan sekitarnya. Tahu putih ditujukan untuk kalangan berpendapatan rendah dengan harganya yang relatif murah. Tahu aman dikonsumsi oleh semua usia, mulai dari balita sampai usia tua, untuk 
laki-laki dan perempuan, yang berpendikan dan yang tidak berpendidikan. Untuk kelas sosial kalangan rendah, untuk gaya hidup kalangan rendah. Karakteristik kepribadian menurut tradisi/kebiasaan konsumen dalam mengkomsumsi tahu putih dikategorikan tinggi. Manfaat dari tahu putih diantaranya ada protein termasuk asam amino esensial, juga berbagai vitamin dan mineral seperti mangan, kalsium, selenium, fosfor, magnesium, zat besi dan lain-lain.

Sasaran pasar utama tahu kuning juga ditujukan untuk wilayah Koto Tangah, dan sekitarnya. Tahu kuning ditujukan untuk kalangan yang berpendatan menengah, karena harganya yang relatif lebih mahal dari tahu putih. Tahu aman dikomsumsi untuk semua usia, mulai dari usia balita hingga tua, untuk laki-laki dan perempuan, yang berpendidikan dan tidak berpendidikan. Untuk kelas sosial kalangan menengah. Untuk gaya hidup kalangan sedang/menengah. Karateristik kepribadian menurut tradisi/kebiasaan konsumen dalam mengkomsumsi tahu kuning dikategorikan rendah. Manfaat tahu kuning diantaranya mengandung isoflavon dapat mencegah penyakit kanker seperti kanker prostat. Dan tingkat penjualan dalam membeli tahu kuning rendah.

Sasaran pasar utama produk tahu bakso juga ditujukan untuk wilayah Koto Tangah dan lingkungan sekitarnya. Tahu bakso ditujukan untuk kalangan yang berpendapatan menengah, maupun tinggi karena harga tahu bakso yang relatif mahal. Tahu bakso tidak bisa dikomsumsi oleh balita, karena bakso sudah ada campuran bahan lainnya, tetapi bisa di komsumsi oleh anak-anak, remaja, dewasa, dan orang tua. Untuk laki-laki dan perempuan, untuk yang berpendidikan dan tidak berpendidikan. Untuk kelas sosial kalangan tinggi. Untuk gaya hidup kalangan tinggi. Karateristik kepribadian menurut tradisi/kebiasaan konsumen dalam mengkomsumsi tahu bakso dikategorikan rendah. Manfaat tahu bakso diantaranya adalah untuk mencukupi kebutuhan protein, tetapi tahu bakso diberikan campuran tepung, ayam dan bahan lainnya.

\section{Positioning Perusahaan Dapur Tahu Alami}

Perusahaan Dapur Tahu Alami telah berusaha untuk membangun image tersendiri untuk penikmat tahu. Positioning di tentukan dari kemampuan perusahaan Dapur Tahu Alami untuk mendiferinsiasikan dirinya secara efektif. Penilaian dan kesan baik, sesungguhnya diciptakan dari berbagai komponen seperti cita rasa yang alami dan tanpa pengenyal.

Produk tahu alami yang dikenal konsumen adalah tahu putih, tahu kuning, dan tahu bakso. Dengan rasa tahunya yang alami dan tanpa pengenyal, diharapkan dapat menunjukkan kepada konsumen tentang letak perbedaan terhadap pesaing, dan inilah yang ditonjolkan oleh perusahaan Dapur Tahu Alami kepada pasar. Kata-kata alami ini mudah dipahami oleh konsumen, sehingga ketika disebutkan alami, maka terlintas di benak konsumen adalah tanpa pengawet, dan tidak ada campuran bahan lainnya. Demikian juga dengan tahu putih, tahu kuning dan tahu bakso yang menjadi ciri khas alami, dan tanpa pengenyal dari Dapur Tahu Alami.

Produk tahu putih di Perusahaan Dapur Alami Lubuk Buaya sudah memiliki nama dimata konsumen, karena tahunya alami dan tanpa pengenyal. Sasaran pasarnya adalah wilayah koto tangah, dan lingkungan sekitarnya, dan sudah memiliki banyak pengecer, usaha olahan tahu, dan rumah tangga dari berbagai wilayah dikota Padang dan diluar kota Padang. Tahu putih aman dikonsumsi untuk semua usia mulai dari balita, anak-anak, remaja, dewasa, dan orang tua. Bisa dikomsumsi untuk laki-laki dan perempuan, untuk yang berpendidikan dan yang tidak berpendidikan. Dilihat dari pendapatan konsumen, tahu putih lebih banyak dibeli oleh konsumen yang berpendapatan rendah, karena harganya yang relatif murah. Bisa dikomsumsi untuk semua kalangan kelas sosial, gaya hidup, dan karakteristik kepribadian. Dan dilihat dari segi manfaat, tahu putih banyak memili manfaat yang membuat tingkat penjualan untuk tahu putih tergolong tinggi.

Produk tahu kuning di Perusahaan Dapur Tahu Alami Lubuk Buaya belum mendapatkan posisi pasar yang baik dimata konsumen, karena harganya yang relatif mahal. Konsumen yang membeli tahu kuning kebanyakan untuk oleh-oleh, dan bukan untuk dijual kembali. Bagi pengecer, usaha olahan tahu, dan rumah tangga lebih memilih tahu putih karena relatif lebih murah. Sasaran pasar tahu kuning adalah wilayah Koto Tangah dan lingkungan sekitarnya. Aman dikomsumsi untuk semua usia mulai dari usia balita, anak-anak, remaja, dewasa, dan orang tua, bisa dikomsumsi untuk laki-laki dan perempuan, dan untuk yang berpendidikan dan tidak berpendidikan. Dan dari segi pendapatan tahu kuning lebih diminati oleh yang berpendapan menengah, ataupun 
tinggi, karena harganya yang relatif mahal. Bisa dikomsumsi untuk semua kalangan kelas sosial, gaya hidup, dan karakteristik kepribadian. Dan dilihat dari segi manfaat tahu kuning juga memiliki banyak manfaat tetapi konsumen lebih memilih tahu putih dan membuat tingkat penjualan dan penggunaan konsumen terhadap tahu kuning tergolong rendah.

Selanjutnya tahu bakso diperusahaan Dapur Tahu Alami Lubuk Buaya belum mendapatkan posisi yang baik dimata konsumen, karena harganya yan relatif mahal. Tahu bakso banyak di beli untuk komsumsi pribadi, dan bukan untuk dijual kembali. Bagi pengecer, usaha olahan tahu, dan rumah tangga jarang membeli tahu bakso karena harganya yang relatif mahal. Hal ini membuat pengecer, usaha olahan tahu, dan rumah tangga berfikir untuk membeli tahu bakso. Sasaran pasar tahu bakso adalah wilayah Koto Tangah dan lingkungan sekitarnya. Tahu bakso tidak bisa dikomsumsi oleh balita, karena bakso sudah ada campuran bahan lainnya. Tetapi aman dikomsumsi oleh anak-anak, remaja, dewasa, dan orang tua, bisa dikomsumsi untuk laki-laki dan perempuan, dan untuk yang berpendidikan dan tidak berpendidikan. Dan dari segi pendapatan tahu bakso lebih diminati oleh yang berpendapan menengah, maupun tinggi karena harganya yangrelatif mahal. Bisa dikomsumsi untuk semua kalangan kelas sosial, gaya hidup, dan karakteristik kepribadian. Dan dilihat dari segi manfaat, tahu bakso juga memiliki banyak manfaat, tetapi tingkat penjualan untuk tahu bakso tergolong rendah, karena harganya yang relatif mahal.

\section{PENUTUP}

Perusahaan telah menerapkan segmentasi secara geografis, demografis, psikografis, dan perilaku. Untuk target pasar Perusahaan sudah menargetkan pasar sasaran utama wilayah Koto Tangah, dan lingkungan sekitarnya. Dan untuk posisi pasar tahu putih dikenal tahu alami tanpa pengenyal, tahu kuning dikenal tahu alami warna kunyit tanpa pengenyal, dan tahu bakso dikenal tahu alami rasa bakso tanpa pengenyal.

\section{E. DAFTAR PUSTAKA}

Kartajaya, Hermawan dan Sula, Muhammad Syakir. (2006). Syariah Marketing. Penerbit Mizan, Bandung

Kotler, Philip dan Amstrong, Gary, (2008). Manajemen Pemasaran. Jakarta: PT. Indeks Kelompok Gramedia, Jakarta.

Manggu, Blasius dan Beni, Sabinus . (2021). Analisis Penerapan Segmentasi, Targeting, Positioning (STP) dan Promosi Pemasaran Sebagai Solusi Meningkatkan Perkembangan UMKM Kota Bengkayang. Jurnal Sebatik Vol. 25 No. 1 Juni 2021.

Nazir, Muhammad. (1988). Metode Penelitian. Penerbit Ghalia Indonesia, Jakarta.

Sakaran, Uma, (2011). Metodologi Penelitian Untuk Bisnis. Terjemahan oleh Kwan Men Yon. Edisi 4. Penerbit Salemba Empat, Jakarta

Tjiptono, Fandy, (2008). Strategi Pemasaran. Penerbit Andi Yogyakarta

Wijaya, Hari dan Sirine, Hani (2016). Strategi Segmenting, Targeting, Positioning Serta Strategi Harga Pada Perusahaan Kecap Blekok di Cilacap. AJIE - Asian Journal of Innovation and Entrepreneurship (e-ISSN: 2477- 0574 ; p-ISSN: 2477-3824) Vol. 01, No. 03, September 2016. 